\title{
THE DETERMINATION OF MAGNESIUM IN BIOLOGICAL FLUIDS AND TISSUES BY FLAME SPECTROPHOTOMETRY
}

\author{
BY \\ NANCY ALCOCK, I. MACINTYRE, AND INGEBORG RADDE \\ From the Department of Chemical Pathology, Postgraduate Medical School, Ducane Road, London
}

(RECEIVED FOR PUBLICATION APRIL 16, 1960)

\begin{abstract}
A flame spectrophotometric method for estimating magnesium in biological fluids and tissues is described. It may be applied to the Zeiss spectrophotometer PMQ II with flame attachment. Interferences are small, and recoveries from plasma and urine and from ashed faeces, soft tissue, and bone are satisfactory. Calcium can be measured on the same dilutions of plasma and urine and faecal ash. Sodium, potassium, calcium, and magnesium can be estimated on the same dilutions of soft tissue and bone ash.

The plasma magnesium concentration of normal subjects falls within a narrow range. Differences between mean normal values previously reported may be partly attributed to the magnesium salt used in preparation of standard solutions.
\end{abstract}

Due to the lack of suitable analytical methods very little is known of the role of magnesium in disease in man. Available methods are either tedious or inaccurate, and plasma magnesium concentrations are estimated in clinical laboratories as rarely as was potassium before the advent of the flame photometer.

Flame photometric estimation is made difficult by the much higher excitation potential of magnesium compared with that of sodium, potassium, and calcium (Mavrodineanu and Boiteux, 1954). The magnesium oxide band at $371 \mathrm{~m} \mu$ is more easily excited than the atomic line at $285.2 \mathrm{~m} \mu$, but has been used only at the expense of a cumbersome internal standard procedure to avoid interference by sodium (Teloh, 1958) or of separate estimation and adjustment of the sample sodium concentration (Wacker and Vallee, 1957). Unfortunately the flame background at $285.2 \mathrm{~m} \mu$ is extremely complex and a further complication is the presence of a sodium line at $285.3 \mathrm{~m} \mu$ (Mavrodineanu and Boiteux, 1954). Hence a very narrow band width must be selected by the monochromator in order to isolate the magnesium emission. This may lead to inadequate sensitivity. Davis (1955), Manna, Strunk, and Adams (1957) and van Fossan, Baird, and Tekell (1959) used an organic solvent to enhance emission, and Kapuscinski, Moss, Zak, and Boyle (1952) attained adequate sensitivity by concentrating the sample after wet oxidation.
This paper describes a simple flame spectrophotometric method which overcomes these difficulties.

\section{EXPERIMENTAL}

The flame spectrophotometer previously described (MacIntyre and Davidsson, 1958) was used with an oxyacetylene flame. Oxyhydrogen gave insufficient sensitivity. The oxygen pressure was set at $25 \mathrm{lb}$./sq. inch, the slit width at $0.02 \mathrm{~mm}$., and the wavelength selector at about $285 \mathrm{~m} \mu$. The peak of the magnesium line was located by noting the maximum deflection on the galvanometer when a concentrated solution (50 $\mathrm{mEq}$./1.) of a magnesium salt was sprayed, while rotating the wavelength selector through 284 to $286 \mathrm{~m} \mu$. The acetylene pressure was then adjusted to produce the greatest possible value of the ratio:

$$
\frac{\text { emission due to magnesium }}{\text { emission due to flame background }}
$$

when a solution of $0.1 \mathrm{mM}$-magnesium salt was sprayed. Sensitivity was judged adequate when this ratio was 1.0 or greater with a $0.1 \mathrm{~mm}$-magnesium solution. The instrument was then ready for taking readings.

Galvanometer deflections of each unknown solution were bracketed between those of the appropriate adjacent standards and readings taken in duplicate. The magnesium content was calculated by interpolation.

\section{Determination of Interference Effects}

All solutions were made with deionized distilled water and were prepared from AnalaR chemicals (British Drug Houses, Poole, England) with the exception of the magnesium and calcium stock solutions. The calcium 
solutions were made from " specpure " calcium carbonate (Johnson, Matthey \& Co. Ltd., London) dissolved in the minimum volume of concentrated $\mathrm{HCl}$. The magnesium stock solution was prepared from " specpure" magnesium sulphate. Polythene containers were used to store all solutions.

In studying interference effects solutions of the same magnesium concentration were prepared containing increasing amounts of the constituent whose effect was being examined. Galvanometer deflections produced by these solutions were recorded. A blank solution in which magnesium was replaced by water, but identical in all other respects, was sprayed in every case.

\section{Method for Determination of Magnesium in Biological Fluids and Tissues}

Stock Solutions.-The following were used :

Magnesium Stock Solution.-A solution of 25 mM-MgSO ${ }_{4} \cdot 7 \mathrm{H}_{2} \mathrm{O}$, of which the concentration was checked by titration with disodium ethylenediaminetetra-acetate which had been standardized with calcium stock solution and with standard zinc acetate solution.

Mixed Salt Solution A.-30 mm-KCl, $5 \mathrm{~mm}-\mathrm{K}_{2} \mathrm{SO}_{4}$, $1.4 \mathrm{M}-\mathrm{NaCl}, 50 \mathrm{~mm}^{-\mathrm{KH}_{2}} \mathrm{PO}_{4}$.

Mixed Salt Solution B.-50 mm-KCl, $5 \mathrm{~mm}-\mathrm{K}_{2} \mathrm{SO}_{4}$, $50 \mathrm{~mm}-\mathrm{NaCl}, 150 \mathrm{~mm}-\mathrm{KH}_{2} \mathrm{PO}_{4}$.

Mixed Salt Solution C. $-2 \mathrm{~mm}-\mathrm{KCl}, 12 \mathrm{~mm}-\mathrm{NaCl}$, 310 mM- $\mathrm{NH}_{4} \mathrm{H}_{2} \mathrm{PO}_{4}$.

Calcium Stock Solution I. $-25 \mathrm{~mm}-\mathrm{CaCl}_{2}$.

Calcium Stock Solution II. $-250 \mathrm{~mm}-\mathrm{CaCl}_{2}$.

Perchloric Acid.- $\mathrm{HClO}_{4} 60 \%$ (w/w).

Hydrochloric Acid.-HCl (S.G. 1.18).

Phosphoric Acid.- $\mathrm{H}_{3} \mathrm{PO}_{4}$ (S.G. 1.75).

Phosphate Solution- $44.4 \mathrm{mM}-\mathrm{KH}_{2} \mathrm{PO}_{4}$.

Sodium Solution. $-200 \mathrm{~mm}-\mathrm{NaCl}$.

Standards for Plasma, Urine, and Faeces.-Solutions were prepared by adding $10 \mathrm{ml}$. of mixed salt solution $\mathrm{A}$, $10 \mathrm{ml}$. calcium solution I, and an appropriate volume of magnesium solution to $700 \mathrm{ml}$. of water in a litre flask. Perchloric acid $(50 \mathrm{ml}$.) was now added and the volume made up to 1 litre. A range of standards at intervals of $0.05 \mathrm{mM}$ was prepared from 0.05 to $0.40 \mathrm{mM}$ with respect to magnesium concentration.

Standards for Soft Tissues.-Standard solutions were prepared to cover the range $0.125-1.00 \mathrm{mM}$ with respect to magnesium concentration at intervals of $0.125 \mathrm{~mm}$. $10 \mathrm{ml}$. of salt solution $\mathrm{B}, 2 \mathrm{ml}$. of calcium solution $\mathrm{I}$, and an appropriate volume of magnesium solution were added to approximately $700 \mathrm{ml}$. of water in a litre flask. $\mathrm{HCl}(100 \mathrm{ml}$.) was added and the volume made up to 1 litre.

Standards for Bone.-Standards to cover the range 0.25-3.0 mM with respect to magnesium concentration were prepared. An appropriate volume of stock standard magnesium solution, together with $100 \mathrm{ml}$. calcium solution II, $100 \mathrm{ml}$. mixed salt solution $\mathrm{C}$, and $100 \mathrm{ml}$. $\mathrm{HCl}$, was made up to 1 litre.
Combined Diluting and Deproteinizing Fluids.-(1) Phosphate solution $(10 \mathrm{ml}$.) was diluted to approximately $700 \mathrm{ml}$. in a volumetric flask, mixed with $55.5 \mathrm{ml}$. $\mathrm{HClO}_{4}$, and made up to 1 litre. This solution was used for plasma and urine analysis.

(2) Phosphate solution (10 ml.) and sodium solution (25 ml.) were diluted to approximately $700 \mathrm{ml}$. in a volumetric flask. Perchloric acid $(55.5 \mathrm{ml}$.) was added and the volume made up to 1 litre. This solution was used for analysis of faecal ash.

(3) $\mathrm{H}_{3} \mathrm{PO}_{4}(1 \mathrm{ml}$.) was added to $\mathrm{HCl}(100 \mathrm{ml}$.) and the volume made up to 1 litre. This solution was used for soft tissue and bone analysis.

\section{Procedure}

Plasma or Serum.-One volume of plasma or serum is added drop by drop to 9 volumes of combined diluting and deproteinizing fluid 1 . The tube is capped with " parafilm" (A. Gallenkamp \& Co. Ltd., London, E.C.2) and the contents mixed by gently inverting the tube several times. It is then centrifuged and the clear supernatant used.

Urine.-Urine may be diluted similarly to plasma, or dilution increased, e.g., 1 in 20 as necessary. Twentyfour-hour urine specimens should be collected in a Winchester bottle containing $10 \mathrm{ml}$. concentrated $\mathrm{HCl}$ in order to prevent precipitation of magnesium.

Faeces.-Specimens were homogenized and a sample dried at $105^{\circ}$ for 16 hours. A known weight (approximately $1.0 \mathrm{~g}$.) was ashed in a platinum crucible at $400^{\prime}$. The ash was dissolved in $\mathrm{N}-\mathrm{HCl}(200 \mathrm{ml}$. $\mathrm{HCl}$ per gram of dry faeces). The solution was thoroughly shaken to ensure complete dissolution. The solution was further diluted as required with combined diluting and deproteinizing fluid 2. Further ten- or twenty-fold dilution was normally appropriate.

Soft Tissues.-Soft tissues were treated as previously described (MacIntyre and Davidsson, 1958). The ash was dissolved in diluting fluid $(4 \mathrm{ml}$. per $20 \mathrm{mg}$. tissue powder).

Bone.-Bone was dried at $105^{\circ}$ for 16 hours. It was defatted by immersing for eight hours in changes $(3 \times 5$ $\mathrm{ml}$.) of a mixture of equal volumes of diethyl ether and light petroleum (B.P. $40^{\circ}-60^{\circ}$ ). The sample was again dried at $105^{\circ}$ for six hours, weighed, and ashed in a platinum crucible at $420^{\prime}$. The ash was dissolved in three or four drops of $\mathrm{HCl}$, taken to dryness and redissolved in diluting fluid $3(40 \mathrm{ml}$. per $200 \mathrm{mg}$. dried fat-free bone).

\section{RESULTS \\ Interference Effects}

Flame Background.-Interference from flame background was studied at $285.2 \mathrm{~m} \mu$ and also at the oxide bands at 371 and $383 \mathrm{~m} \mu$. Results are summarized in Table I. The background interference is least at $285.2 \mathrm{~m} \mu$.

Sodium Emission at $285.3 \mathrm{~m} \mu$.- - It is essential that the maximum resolution be employed to minimize 
TABLE I

EMISSION DUE TO SODIUM AND MAGNESIUM

\begin{tabular}{|c|c|c|c|}
\hline & $285.2 \mathrm{~m} \mu$ & $371 \mathrm{~m} \mu$ & $383 \mathrm{~m} \mu$ \\
\hline $\begin{array}{l}\text { Ratio } \frac{\mathrm{Mg} \text { emission }(0.1 \mathrm{~mm}-\mathrm{Mg})}{\text { flame background }} \\
{ }^{*} \mathrm{Na} \text { interference }(0.1 \mathrm{mM}-\mathrm{Mg} ; \\
20 \mathrm{mM}-\mathrm{Na}) \quad \ldots \quad \ldots\end{array}$ & $1 \cdot 0-1 \cdot 5$ & $\begin{array}{l}0.03 \\
500\end{array}$ & 0.03 \\
\hline
\end{tabular}

* $\mathrm{Na}$ interference was expressed by the ratio: $\frac{\text { emission due to sodium }}{\text { emission due to magnesium }} \times 100$

the interference due to the sodium emission at $285.3 \mathrm{~m} \mu$. The emission spectrum of a solution containing $0.1 \mathrm{~mm}$-magnesium and $20 \mathrm{~mm}-\mathrm{NaCl}$ solutions was studied. These concentrations are similar to the proportions of magnesium and sodium in plasma. It was found that the emission due to sodium was $2 \%$ of that due to magnesium. The emission of magnesium at the oxide bands at 371 and $383 \mathrm{~m} \mu$ was also studied. Comparison of the emissions due to magnesium and to sodium are summarized in Table I.

Other Inorganic Constituents.-Potassium chloride, calcium chloride, ammonium sulphate, ammonium dihydrogen phosphate, and potassium dihydrogen phosphate in concentrations up to $20 \mathrm{~mm}$ had no effect on $\mathrm{Mg}$ emission at $285.2 \mathrm{~m} \mu$.

$\mathrm{HCl}, \mathrm{HClO}_{4}$, and $\mathrm{H}_{3} \mathrm{PO}_{4}$ in the concentrations used were without effect on magnesium emission.

Organic Constituents.-Samples of pooled human plasma were ashed at $400^{\circ}$ for 16 hours. Magnesium was estimated on the ash and the results compared with those obtained by direct estimation (Table IV). Agreement was good. Hence organic constituents present in plasma are without effect on magnesium emission.

\section{Recovery Experiments}

Recoveries of magnesium added to plasma and urine are shown in Tables II and III respectively. Pooled human plasma of low magnesium content was prepared by passing through a column of "zeocarb 225 " cation exchange resin (Permutit

TABLE II

RECOVERY OF MAGNESIUM ADDED TO PLASMA

\begin{tabular}{|c|c|c|c|c|}
\hline $\begin{array}{c}\text { Sample } \\
\text { No. }\end{array}$ & $\begin{array}{c}\text { Obtained } \\
\text { (mEq./1.) } \\
(\text { a) }\end{array}$ & $\begin{array}{c}\text { Expected } \\
\text { (mEq./1.) } \\
\text { (b) }\end{array}$ & $\begin{array}{c}\text { Difference } \\
\text { (mEq./l.) } \\
(a-b)\end{array}$ & $100 a / b$ \\
\hline $\begin{array}{l}1 \\
2 \\
3 \\
4 \\
5 \\
6 \\
7 \\
8\end{array}$ & $\begin{array}{l}0.32 \\
0.79 \\
1 \cdot 33 \\
1.82 \\
2 \cdot 37 \\
2.89 \\
\mathbf{3} \cdot 48 \\
\mathbf{3} \cdot 91\end{array}$ & $\begin{array}{l}\overline{0.82} \\
1 \cdot 32 \\
1 \cdot 82 \\
2 \cdot 32 \\
2 \cdot 82 \\
3 \cdot 32 \\
3 \cdot 82\end{array}$ & $\begin{array}{r}-\overline{0.03} \\
+0.01 \\
0 \\
+0.05 \\
+0.07 \\
+0.16 \\
+0.09\end{array}$ & $\begin{array}{r}\overline{96 \cdot 3} \\
100 \cdot 8 \\
100 \cdot 0 \\
102 \cdot 2 \\
102 \cdot 5 \\
104 \cdot 8 \\
102 \cdot 4\end{array}$ \\
\hline $\begin{array}{l}\text { Mean } \\
( \pm \text { S.E. })\end{array}$ & & & $+0.050( \pm 0.024)$ & $101 \cdot 3( \pm 1 \cdot 01)$ \\
\hline
\end{tabular}

Co. Ltd., London, W.4). The calcium, potassium, and sodium contents of the plasma were adjusted to $5.0,5.0$, and $140.0 \mathrm{mEq}$./1. respectively, by adding appropriate amounts of $\mathrm{CaCl}_{2}, \mathrm{KCl}$, and $\mathrm{NaCl}$. Varying amounts of magnesium (as magnesium sulphate) were added to samples of the pooled plasma. Magnesium was then estimated in each sample, determinations being carried out in quadruplicate.

TABLE IIIa

RECOVERY OF MAGNESIUM ADDED TO RAT URINE

\begin{tabular}{|c|c|c|c|c|}
\hline $\begin{array}{c}\text { Sample } \\
\text { No. }\end{array}$ & $\begin{array}{c}\text { Obtained } \\
\text { (mEq./1.) } \\
(a)\end{array}$ & $\begin{array}{c}\text { Expected } \\
\text { (mEq./1.) } \\
\text { (b) }\end{array}$ & $\begin{array}{c}\text { Difference } \\
(\mathrm{mEq} / \mathrm{l} .) \\
(a-b)\end{array}$ & $100 a / b$ \\
\hline $\begin{array}{l}1 \\
2 \\
3 \\
4 \\
5 \\
6 \\
7 \\
8 \\
9\end{array}$ & $\begin{array}{l}0 \cdot 02 \\
1 \cdot 06 \\
2 \cdot 08 \\
3 \cdot 16 \\
4 \cdot 18 \\
4 \cdot 81 \\
6 \cdot 04 \\
7 \cdot 13 \\
8 \cdot 11\end{array}$ & $\begin{array}{l}1.02 \\
2.02 \\
3.02 \\
4.00 \\
5.00 \\
6.00 \\
7.00 \\
8.00\end{array}$ & $\begin{array}{r}-\overline{0.04} \\
+0.06 \\
+0.14 \\
+0.18 \\
-0.19 \\
+0.04 \\
+0.13 \\
+0.11\end{array}$ & $\begin{array}{r}\overline{103 \cdot 9} \\
103 \cdot 0 \\
104 \cdot 6 \\
104 \cdot 5 \\
96 \cdot 2 \\
100.7 \\
101 \cdot 9 \\
101.4\end{array}$ \\
\hline $\begin{array}{l}\text { Mean } \\
( \pm \text { S.E. })\end{array}$ & & & $0.064( \pm 0.040)$ & $102.0( \pm 0.98)$ \\
\hline
\end{tabular}

TABLE IIIb

RECOVERY OF MAGNESIUM ADDED TO RANDOM SPECIMENS OF HUMAN URINE

\begin{tabular}{|c|c|c|c|c|c|}
\hline $\begin{array}{c}\text { Sample } \\
\text { No. }\end{array}$ & $\begin{array}{c}\text { Obtained } \\
\text { (mEq./1.) } \\
(a)\end{array}$ & $\begin{array}{c}\text { Expected } \\
\text { (mEq./l.) } \\
(\text { b) }\end{array}$ & $\begin{array}{c}\text { Difference } \\
\text { (mEq./1.) } \\
(a-b)\end{array}$ & $100 a / b$ & $\underset{\text { tion }}{\text { Descrip- }}$ \\
\hline 1 & $10 \cdot 94$ & $11 \cdot 15$ & $-0 \cdot 21$ & $98 \cdot 1$ & Calcium \\
\hline 2 & $2 \cdot 10$ & 1.99 & +0.11 & $105 \cdot 5$ & $\begin{array}{l}\text { Glucose } \\
(300 \mathrm{mg} . / \\
100 \mathrm{ml} .)\end{array}$ \\
\hline 3 & $3 \cdot 43$ & 3.47 & -0.04 & $98 \cdot 8$ & $\begin{array}{l}\text { Protein } \\
(0.5 \mathrm{gg} /) \\
100 \mathrm{ml} .)\end{array}$ \\
\hline 4 & $7 \cdot 12$ & $7 \cdot 26$ & -0.14 & $98 \cdot 1$ & Bile + uro- \\
\hline $\begin{array}{r}5 \\
6 \\
7 \\
8 \\
9 \\
10\end{array}$ & $\begin{array}{l}3.56 \\
5.52 \\
9.82 \\
4.49 \\
3.84 \\
4 \cdot 24\end{array}$ & $\begin{array}{l}3.44 \\
5.27 \\
9.96 \\
4.48 \\
3.85 \\
4.37\end{array}$ & $\begin{array}{r}+0.12 \\
+0.25 \\
+0.14 \\
+0.01 \\
-0.01 \\
-0.13\end{array}$ & $\begin{array}{r}103 \cdot 5 \\
104.7 \\
98 \cdot 6 \\
100 \cdot 2 \\
99 \cdot 7 \\
97 \cdot 0\end{array}$ & $\begin{array}{c}\text { Normal } \\
\text {," } \\
\text {," } \\
\text {," }\end{array}$ \\
\hline $\begin{array}{l}\text { Mean } \\
( \pm \text { S.E. })\end{array}$ & & & $\begin{array}{c}-0.018 \\
( \pm 0.047)\end{array}$ & $\begin{array}{l}100.4 \\
( \pm 0.96)\end{array}$ & \\
\hline
\end{tabular}

*Abnormal components of urine are shown under the heading "Description."

Urine of low magnesium content obtained from magnesium-deficient rats was used for recovery experiments (Table IIIa). In addition a constant amount of magnesium was added to human urine specimens of differing composition (Table IIIb).

Varying amounts of magnesium were added to dried homogenized faeces, dried muscle which had previously been defatted and homogenized, and to dried defatted bone. Recovery of magnesium added to samples of each is shown in Tables V, VI, and VII respectively. 
TABLE IV

COMPARISON OF PLASMA MAGNESIUM ESTIMATIONS BEFORE AND AFTER ASHING AT $400^{\circ}$

\begin{tabular}{|c|c|c|c|c|}
\hline $\begin{array}{c}\text { Sample } \\
\text { No. }\end{array}$ & $\begin{array}{c}\text { After } \\
\text { Ashing } \\
\underset{(\text { (a) }}{\text { (mEq.) }}\end{array}$ & $\begin{array}{c}\text { Before } \\
\text { Ashing } \\
\text { (mEq./1.) } \\
(\text { b })\end{array}$ & $\begin{array}{c}\text { Difference } \\
\text { (mEq./1.) } \\
(a-b)\end{array}$ & $100 a / b$ \\
\hline $\begin{array}{r}1 \\
2 \\
3 \\
4 \\
5 \\
6 \\
7 \\
8 \\
9 \\
10\end{array}$ & $\begin{array}{l}1.56 \\
1.56 \\
1.56 \\
1.75 \\
1.47 \\
1.50 \\
1.60 \\
1.74 \\
1.25 \\
1.31\end{array}$ & $\begin{array}{l}1.56 \\
1.56 \\
1.62 \\
1.81 \\
1.47 \\
1.50 \\
1.60 \\
1.71 \\
1.38 \\
1.38\end{array}$ & $\begin{array}{l}0 \\
0 \\
-0.06 \\
-0.06 \\
0 \\
0 \\
0 \\
+0.03 \\
-0.13 \\
-0.07\end{array}$ & $\begin{array}{c}100 \\
100 \\
96 \cdot 3 \\
96 \cdot 7 \\
100 \\
100 \\
100 \\
101 \cdot 8 \\
90 \cdot 6 \\
94 \cdot 9\end{array}$ \\
\hline $\begin{array}{l}\text { Mean } \\
( \pm \text { s.E. })\end{array}$ & & & $-0.029( \pm 0.015)$ & $98.03( \pm 1.07)$ \\
\hline
\end{tabular}

TABLE V

RECOVERY OF MAGNESIUM FROM DRIED FAECES

\begin{tabular}{|c|c|c|c|c|}
\hline $\begin{array}{c}\text { Sample } \\
\text { No. }\end{array}$ & $\underset{(a)}{\text { Obtained }} \underset{(\mu \mathrm{Eq} . / \mathrm{g} .)}{(a)}$ & $\begin{array}{c}\text { Expected } \\
(\mu \mathrm{Eq} . / \mathrm{g} .) \\
(\text { b })\end{array}$ & $\begin{array}{l}\text { Difference } \\
(\mu \mathrm{Eq} \cdot / \mathrm{g} .) \\
(a-b)\end{array}$ & $100 a / b$ \\
\hline $\begin{array}{l}1 \\
2 \\
3 \\
4 \\
5 \\
6 \\
7 \\
8\end{array}$ & $\begin{array}{l}368 \\
430 \\
132 \\
504 \\
464 \\
166 \\
230 \\
302\end{array}$ & $\begin{array}{l}370 \\
400 \\
140 \\
496 \\
430 \\
170 \\
240 \\
294\end{array}$ & $\begin{array}{r}-2 \\
+30 \\
-8 \\
+8 \\
+34 \\
-4 \\
-10 \\
+8\end{array}$ & $\begin{array}{r}99.5 \\
107.5 \\
94.3 \\
101.6 \\
107.9 \\
97.6 \\
95.8 \\
102.7\end{array}$ \\
\hline $\begin{array}{l}\text { Mean } \\
( \pm \text { S.E. })\end{array}$ & & & $7( \pm 5 \cdot 9)$ & $100.9( \pm 1.8)$ \\
\hline
\end{tabular}

\section{Normal Plasma Values}

Blood from 76 healthy adults (either laboratory personnel or blood donors) was collected into bottles containing sodium heparin. The magnesium concentration was estimated in duplicate. The mean \pm the S.E. was $1.66 \pm 0.01 \mathrm{mEq} . / 1$. The distribution is shown in the histogram (Fig. 1). No sex differences in magnesium concentration were found. The narrow range in which the magnesium values in plasma of healthy adults falls is striking.

After this work had been completed a Zeiss spectrophotometer PMQ II with single monochromator M4QII or double monochromator MM12 (Carl Zeiss, Oberkochen, Germany) with flame attachment became available. The burner was modified by enlarging the fuel inlet to $1.3 \mathrm{~mm}$. An oxyacetylene flame was used at pressures of $250 \mathrm{~mm}$. water and $0.37 \mathrm{~kg}$. $/ \mathrm{sq}$. cm. for acetylene and oxygen respectively. Magnesium estimations were made at $285.2 \mathrm{~m} \mu$ with a slit width of $0.0175 \mathrm{~mm}$. (single monochromator) or $0.02 \mathrm{~mm}$. (double monochromator)
TABLE VI

RECOVERY OF MAGNESIUM FROM DRIED FAT-FREE MUSCLE

\begin{tabular}{|c|c|c|c|c|}
\hline $\begin{array}{c}\text { Sample } \\
\text { No. }\end{array}$ & $\begin{array}{c}\text { Obtained } \\
\text { (mEq./ } \\
\text { kg.) } \\
(a)\end{array}$ & $\begin{array}{c}\text { Expected } \\
\text { (mEq./ } \\
\text { kg.) } \\
(\text { b) }\end{array}$ & $\begin{array}{c}\text { Difference } \\
\text { (mEq./kg.) } \\
(a-b)\end{array}$ & $100 a / b$ \\
\hline $\begin{array}{l}1 \\
2 \\
3 \\
4 \\
5 \\
6 \\
7 \\
8\end{array}$ & $\begin{array}{l}121.3 \\
140.9 \\
124.2 \\
135.4 \\
125.0 \\
137.6 \\
136.6 \\
148.0\end{array}$ & $\begin{array}{l}123.6 \\
141.6 \\
127.2 \\
140.2 \\
127.4 \\
135.0 \\
136.6 \\
145.6\end{array}$ & $\begin{array}{r}-2.3 \\
-0.7 \\
-3.0 \\
-4.8 \\
-2.4 \\
+2.6 \\
0 \\
+2.4\end{array}$ & $\begin{array}{r}98 \cdot 1 \\
99.5 \\
97.6 \\
96.6 \\
98 \cdot 1 \\
101.9 \\
100.0 \\
101.6\end{array}$ \\
\hline $\begin{array}{l}\text { Mean } \\
( \pm \text { s.E. })\end{array}$ & & & $-1.025( \pm 0.92)$ & $99 \cdot 2( \pm 0 \cdot 7)$ \\
\hline
\end{tabular}

TABLE VII

RECOVERY OF MAGNESIUM FROM DRIED DEFATTED BONE

\begin{tabular}{|c|c|c|c|c|}
\hline $\begin{array}{c}\text { Sample } \\
\text { No. }\end{array}$ & $\begin{array}{c}\text { Obtained } \\
\text { (mEq./ } \\
\text { kg.) } \\
\text { (a) }\end{array}$ & $\begin{array}{c}\text { Expected } \\
\text { (mEq./ } \\
\text { kg.) } \\
(\text { b) }\end{array}$ & $\begin{array}{l}\text { Difference } \\
\text { (mEq./kg.) } \\
\underset{(a-b)}{ }\end{array}$ & $100 a / b$ \\
\hline $\begin{array}{r}1 \\
2 \\
3 \\
4 \\
5 \\
6 \\
7 \\
8 \\
9 \\
10 \\
11 \\
12\end{array}$ & $\begin{array}{l}408 \\
445 \\
450 \\
479 \\
435 \\
478 \\
468 \\
555 \\
478 \\
531 \\
532 \\
602\end{array}$ & $\begin{array}{l}425 \\
464 \\
428 \\
472 \\
418 \\
465 \\
480 \\
528 \\
468 \\
530 \\
525 \\
595\end{array}$ & $\begin{array}{r}-17 \\
-19 \\
+22 \\
+7 \\
+17 \\
+13 \\
-12 \\
+27 \\
+10 \\
+1 \\
+7 \\
+7\end{array}$ & $\begin{array}{r}96.0 \\
95.9 \\
105.0 \\
101.5 \\
104.1 \\
102.8 \\
97.5 \\
105.1 \\
102.1 \\
100.2 \\
101.3 \\
101.2\end{array}$ \\
\hline $\begin{array}{l}\text { Mean } \\
( \pm \text { s.E. })\end{array}$ & & & $+5 \cdot 25( \pm 4 \cdot 25)$ & $101 \cdot 1( \pm 0.92)$ \\
\hline
\end{tabular}

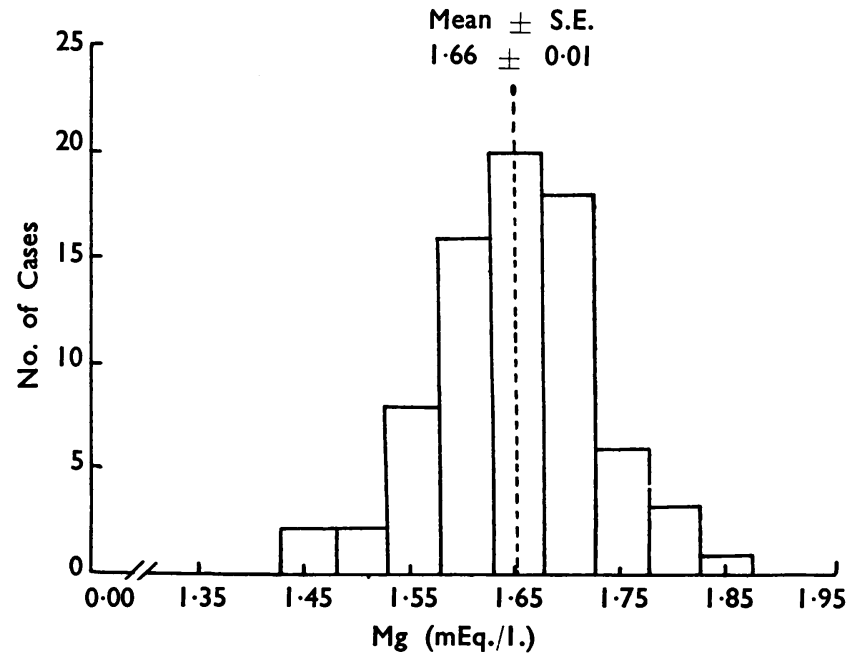

Fig. 1.-Histogram of plasma magnesium levels in 76 healthy adults. 
and the instrument adjusted to full sensitivity. Interference effects were almost identical with those described and the instrument is entirely satisfactory for the estimation of magnesium in plasma, urine, faeces, soft tissues, and bone. Background interference is least with the double monochromator MM12.

\section{DISCUSSION}

The difficulty in estimating the concentration of magnesium from its emission at $285.2 \mathrm{~m} \mu$ arises from several sources. The excitation potential of the magnesium line at $285.2 \mathrm{~m} \mu$ is $4.3 \mathrm{eV}$ compared with values of $2.1,1.6$, and 2.9 for the emission of sodium at $589 \mathrm{~m} \mu$, potassium at $766.5 \mathrm{~m} \mu$, and calcium at $422.7 \mathrm{~m} \mu$ respectively. It is therefore necessary to use a hot flame such as oxyacetylene to obtain sufficient sensitivity. Further, even the emission obtained with an oxyacetylene flame is small and requires a photomultiplier for its detection and measurement.

A monochromator of high resolution is necessary to separate the emission of magnesium at $285.2 \mathrm{~m} \mu$ from the adjacent sodium emission at $285.3 \mathrm{~m} \mu$, and from the complex flame background in this region of the spectrum.

The dilutions of muscle and bone ash described are suitable for the simultaneous determination of sodium, potassium, calcium, and magnesium.

Phosphate, sulphate, calcium, and potassium in concentrations encountered in biological fluids were without detectable influence on magnesium emission. Interference due to sodium was $2 \%$ or less. Sodium, potassium, calcium, phosphate, and sulphate were incorporated in the standards to allow for any complex interference effects from the presence of mixed salt undetected from interference studies of individual compounds. Excess phosphate was added to allow simultaneous measurement of calcium (MacIntyre, 1957).

Table VIII summarizes some recent values quoted for normal plasma magnesium. A difference of about $25 \%$ in the mean value obtained is evident, and may be attributed in part to the source of magnesium used in preparation of standard solutions. Magnesium oxide is not a suitable standard substance: it is difficult to prepare pure and it absorbs carbon dioxide from the air (Mellor, 1923). Complete decomposition of magnesium carbonate only occurs at $900^{\circ}$ (Mellor, 1923). The mean normal value obtained using standards prepared from magnesium oxide treated in this way (Davis, 1955; Carr and Frank, 1956) is in agreement with
TABLE VIII

MEAN NORMAL VALUES REPORTED FOR PLASMA MAGNESIUM

\begin{tabular}{|c|c|c|c|}
\hline Author & Method & $\begin{array}{c}\text { Standard } \\
\text { Magnesium } \\
\text { Salt }\end{array}$ & $\begin{array}{c}\text { Mean } \\
\text { Normal } \\
\text { (mEq./1.) }\end{array}$ \\
\hline Davis (1955) .. & $\begin{array}{c}\text { Flame spectro- } \\
\text { photometric }\end{array}$ & $\begin{array}{l}\text { MgO heated to } \\
800-900^{\circ} \text { for }\end{array}$ & 1.66 \\
\hline $\begin{array}{l}\text { Carr and Frank } \\
(1956)\end{array}$ & $\begin{array}{l}\text { Titration with } \\
\text { E.D.T.A. }\end{array}$ & $\begin{array}{l}\text { several hours } \\
\text { MgO heated to } \\
\text { constant }\end{array}$ & $1 \cdot 72$ \\
\hline $\begin{array}{l}\text { van Fossan et al. } \\
\text { (1959) }\end{array}$ & $\begin{array}{c}\text { Flame spectro- } \\
\text { photometric }\end{array}$ & $\begin{array}{l}\text { weight } \\
\text { Pure Mg metal }\end{array}$ & 1.67 \\
\hline Hunter (1958) & $\begin{array}{l}\text { Matching the colour } \\
\text { with eriochrome } \\
\text { black T with } \\
\text { standard }\end{array}$ & Mg ribbon & 1.69 \\
\hline $\begin{array}{l}\text { Simonsen et al. } \\
\text { (1947) }\end{array}$ & $\begin{array}{l}\text { Phosphate } \\
\text { precipitation }\end{array}$ & - & 1.68 \\
\hline Schachter (1959) & Fluorimetric & $\begin{array}{l}\text { Reagent grade } \\
\text { MgO heated } \\
\text { to } 110^{\circ}\end{array}$ & 2.05 \\
\hline $\begin{array}{l}\text { Wacker and } \\
\text { Vallee (1957) }\end{array}$ & $\begin{array}{c}\text { Flame spectro- } \\
\text { photometric }\end{array}$ & $\begin{array}{c}\text { Reagent grade } \\
\text { MgO heated } \\
\text { to } 120^{\circ}\end{array}$ & 2.05 \\
\hline Present series & ," & MgSO & 1.66 \\
\hline
\end{tabular}

that obtained when the source is pure magnesium metal (van Fossan et al., 1959; Hunter, 1958) or magnesium sulphate as used in this method. Indirect measurement of plasma magnesium by phosphate precipitation gives similar results (Simonsen, Westover, and Wertman, 1947).

Magnesium oxide heated to $110^{\circ}$ or $120^{\circ}$ would be expected to produce high results and this is seen to be the case (Schachter, 1959; Wacker and Vallee, 1957).

We should like to thank the Medical Research Council for financial support. Most of the work described in this paper is from a Ph.D. thesis (University of London) by I. MacI.

\section{REFERENCES}

Carr, M. H., and Frank, H. A. (1956). Amer. J. clin. Path., $26,1157$. Davis, S. (1955). J. biol. Chem., 216, 643.

Hunter, G. (1958). Nature (Lond.), 182, $263-4$.

Kapuscinski, V., Moss, N., Zak, B., and Boyle, A. J. (1952). Amer. J. clin. Path., 22, 687.

MacIntyre, I. (1957). Biochem. J., 67, 164.

and Davidsson, D. (1958). Ibid., 70, 456.

Manna, L., Strunk, D. H., and Adams, S. L. (1957). Analyt. Chem $29,1885$.

Mavrodineanu, R., and Boiteux, H. (1954). L'Analyse Spectrale Quantitative par la Flamme, p. 152. Masson, Paris.

Mellor, J. W. (1923). A Comprehensive Treatise on Inorganic and Theoretical Chemistry, Vol. IV, p. 288. Longmans Green, London.

Schachter, D. (1959). J. Lab. clin. Med., 54, 763.

Simonsen, D. G., Westover, L. M., and Wertman, M. (1947). J. biol. Chem., 169, 39.

Teloh, H. A. (1958). Amer. J. clin. Path., 30, 129.

Van Fossan, D. D. Baird, E. E., ana Tekell, G. S. (1959). Ibid., 31, 368.

Wacker, W. E. C., and Vallee, B. L. (1957). New Engl. J. Med., 257, 1254. 